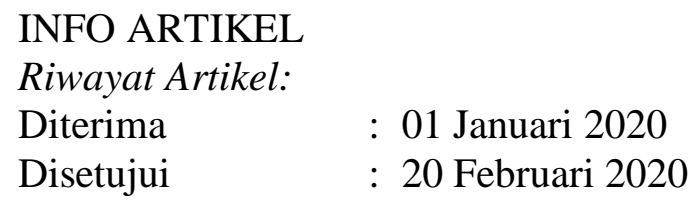

GEOGRAFI

\title{
KONDISI SOSIAL EKONOMI MASYARAKAT YANG BEKERJA PADA SEKTOR INFORMAL DI KELURAHAN PASAR BHAYANGKARA KECAMATAN TALANG UBI KABUPATEN PALI
}

\author{
Reni Zuanita ${ }^{1}$, Boby Agus Yusmiono², Yasir Arafat ${ }^{3}$ \\ ${ }^{1-2}$ Fakultas Keguruan dan Ilmu Pendidikan Geografi, Universitas PGRI Palembang \\ ${ }^{3}$ Program Studi Manajemen, Fakultas Ekonomi, Universitas PGRI Palembang \\ $(\triangle)$ zuanitareni@gmail.com ${ }^{1}$; boby.yusmiono@yahoo.com²; yasir_arafat14@yahoo.com ${ }^{3}$
}

\begin{abstract}
ABSTRAK
Penelitian ini dilakukan Untuk mengetahui faktor yang membuat masyarakat di Kelurahan Pasar Bhayangkara Kecamatan Talang Ubi KabupatenPALI bekerja di sektor informal dan juga untuk mengetahui kondisi sosial ekonomi masyarakat yang bekerja di sektor informal. Penelitian ini menggunkan metode penelitian deskriptif kualitatif dengan dasar-dasar metode studi kasusdan menggunakan pendekatan kualitatif, dengan pendekatan kualitatif, maka data-data yang diperoleh dalam prosedur penelitian ini merupakan data-data deskriptif. Teknik pengumpulan data yang digunakan dalam penelitian ini yaitu Wawancara 2). Dokumentasi, dan 3). Observasi Langsung. Teknik Analisis data melalui prosedur dan tahapantahapan berikut: 1. Reduksi Data, 2. Penyajian Data dan 3. Conclusion Drawing/Veriffication. Hasil dari wawancara menunjukkan bahwa masyarakat pekerja sektor informal memiliki pendidikan rendah, itulah yang menjadi penyebab masyarakat bekerja di sektor informal, selain pendidikan juga masalah lingkungan yang kebanyakan bekerja di sektor informal, pendapatan para pekerja sektor informal paling kecil yaitu 200 ribu rupiah perharinya.
\end{abstract}

Kata kunci: kondisi sosial ekonomi, sektor informal

\section{PENDAHULUAN}

Kabupaten PALI khususnya di pasar bhayangkara memiliki kondisi geografis yang dapat dikatakan strategis karena letak pasar Bhayangkara ini berada di tengah permukiman penduduk, posisi pasar bhayangkara berada didekat terminal, rumah sakit, sekolah dan fasilitas umum lainnya, pedagang yang berdagang di pasar bhayangkara tidaklah berasal dari kelurahan pasar bhayangkara, seperti contoh pedagang sayur dan buah, pedang sayur dan buah di pasar bhayangkara banyak berasal dari desa lain, hal ini disebabkan oleh keadaan geografis disekitar kelurahan pasar bhayangkara tidak lah memungkinkan untuk dibukanya lahan perkebunan sayur dan buah, karena keadaan rumah penduduk yang dapat dikatakan padat.

Dari pendekatan geografi oleh Pattison disebut juga sebagai tradisi-tradisi geografi meliputi apa yang olehnya digolongkan atas: (1) tradisi keruangan, yang perhatiannya lebih terpusat pada persoalam geometri hubungan-hubungan keruangan dan juga perpindahan keruangan; (2) tradisi studi wilayah, yang perhatiannya terpusat pada kajian karakteristik esensial tempat-tempat atau kawasan; (3) tradisi kajian hubungan manusiaalam, yang perhatiannya terpusat pada perkara 
interaksi manusia dengan lingkungannya; dan (4) tradisi ilmu kebumian, yang perhatiannya terutama terpusat pada upaya mendeskripsikan dan menjelaskan ciri-ciri permukaan bumi (Suharyono, Amien, 2013:47).

Dari penjelasan di atas maka dapat ditarik kesimpulan bahwa keadaan pasar ini termasuk kedalam ilmu kajian geografi ekonomi cabang geografi manusia dalam konteks keruangan yang perhatiannya terpusat pada kajian karakteristik esensial tempat dan juga kawasan di sekitar pasar Bhayangkara, keadaan tempat yang strategis memungkinkan adanya interaksi sosial antar masyarakat, misalnya melakukan transaksi jual beli untuk tujuan menguntungkan dan diuntungkan demi mempertahankan hidup.

Urban Fringe adalah suatu daerah batas luar kota yang sifatnya mirip dengan kota. (Eva Banowati, 2013 : xiv). Pertemuan kota (city) dan desa (rural) ada istilah dengan : city, suburban, suburban fringe, urban fringe, rural urban fringe dan rural. Pasar bayangkara bukan Rural urban fringe adalah lahan campuran antara desa dan kota.

Indonesia sejatinya berakar pada, dan dibangun diatas, sumber-sumber primodial dan tradisonal yang tersedia, secara terbuka berproses untuk saling mematankan diri memalui dialog yang tersedia, dan secara terbuka berproses untuk saling mematangkan diri melaui dialog budaya yang kreatif lagi produktif. (Komaruddin Hidayat dan Putut Widjanarko, 2008 : 454). Primodial adalah kesukuan dimana menjadi kekuatan modal sosial seperti pedagang hal ini diperkuat dengan adanya sistem kekeluargaan dalam perdangan mereka atau bisa disebut usaha keluarga turun-temurun.

Primodial merupakan modal sosial dan ekonomi dalam melaksanakan terciptanya perdagangan di pasar bhayangkara kebanyakan suku Pasemah. Tradisi oriental mengatakan bahwa prinsip primodial adalah Chaos (Kacau), kemudian Chaos ini bersatu dengan roh melahirkan Mot (sabda) (Wibowo, 2004 : 147). Primodial itu merupakan perpaduan kebiasaan masyarakat yang berdagang. Berdagang memang bisa dimana saja yang akan menciptakan kecauan misalnya kotor, kumuh, kriminalitas. Sehingga ada baiknya jika tempat berdagang diatur oleh pemerintah daerah tersebut.

Perencanaan di tingkat nasional dengan desentralisasi dalam pelaksanaan kegiatan ekonomi untuk menjamin keadilan ekonomi dan sosial. (Nikmatul Masruroh dan Agung Parnomo, 2018 : 17) ekonomi kerakyatan sokongan terbesar dari ekonomi dan sosial adalah modal atau kapital yang didapat dalam menjalankan simpan pinjam (koperasi) dalam roda perekonomian perdesaan.

Pada dasarnya, sistem ekonomi kerakyatan adalah sistem ekonomi berdasarkan kekeluargaan, berkedaulatan rakyat, bermoral pancasila, dan menunjukkan pemihakan sungguh-sungguh pada rakyat yang lemah. pemihakan kepada rakyat ini seharusnya diwijudkan pemerintah melalui berbagai kebijakan dan regulasi yang dikeluarkan. sistem ekonomi kerakyatan sesungguhnya tidak menafikan begitu saja adanya mekanisme pasar. Namun berbeda dengan mekanisme pasar yang dianut sistem ekonomi neoliberal, sistem ekonomi kerakyatan lebih mengedepankan perlindungan dan pemihakan bagi pelaku ekonomi lemah yang belum mampu untuk bersaing secara bebas di pasar dengan pemberdayaan ekonomi rakyat (Radhi $2008: 188$ )

Dalam memperkuat sosial -ekonomi di tompang juga dengan media masa menurut Atep Adya Barata ada tiga jenis media komunikasi : Media komunikasi audio, media komunikasi visual dan media komunikasi audio visual. (Atep Adya Barata, 2004 : 110). Media merupakan komunikasi antara individu dengan individu, indivudu dengan kelompok, dan kelompok dengan kolompok. Sehingga sosial ekonomi berjalan dengan kuat, apalagi ada juga wakil persiden pertama muh. hatta membahas ekonomi kerakyatan yang erat kaitannya membahas perdesaan. Sehingga desa menjadi daerah Urban Fringe (luar kota mirip dengan kota).

Sektor informal ditandai oleh beberapa karakteristik unik seperti sangat bervariasi bidang kegiatan produksi barang dan jasa, berskala kecil, unit-unit produksinya dimiliki secara perorangan atau keluarga, banyak menggunakan tenaga kerja (padat karya), dan teknologi yang dipakai relatif 
sederhana. sektor informal cenderung beroperasi seperti halnya perusahaan persaingan monopolistik yang bercirikan mudanya laba (pendapatan) menuju rata-rata harga penawaran tenaga kerja potensial yang baru. para pekerja yang menciptakan formal. pada umumnya, mereka tidak mempunyai keterampilam khusus dan sangat kekurangan modal kerja. oleh sebab itu, produktivitas dan pendapatan mereka cenderung lebih rendah daripada kegiatan-kegiatan bisnis yang ada di sektor formal. Selain itu, mereka yang berada di sektor informal tersebut juga tidak memiliki jaminan keselamatan kerja dan fasilitasfasilitas kesejahteraan seperti yang dinikmati rekan-rekan mereka di sektor formal, misalnya tunjangan keselamatan kerja dan dana pensiun. Umumnya, mereka hanya terbatas pada upaya untuk mempertahankan kelangsungan hidup, agar bisa makan pada hari ini atau esok, dan bukan untuk menumpuk keuntungan apabila kekayaan. satu-satunya yang dapat dan harus mereka andalkan adalah diri mereka semata. Bila pendatang itu sebuah keluarga, maka hampir seluruh waktu mereka habiskan untuk itu. sebagian dari mereka tinggal di pusat permukiman sangat sederhana (Todaro dan Smith, $2006: 393$ )

Sektor informal terkait dengan sektor perdesaan dalam pengertian kawasan atau sektor pedesaan merupakan suber tenaga kerja miskin yang berlebih, yang kemudian mengusi sektor informal di daerah perkotaan guna menghindari kemiskinan dan pengaguran di desa, walupun, sebenarnya kondisi kerja dan kualitas hidup di kota belum tentu lebih baik. Selain itu, sektor informal juga terkait erat dengan sektor formal perkotan ; yaitu sektor formal bergantung pada sektor informal dalam menyediaan input-input produksi dan tenaga kerja murah, sedangkan sektor informal sangat tergantung pada sektor formal dalam kedudukan sebagai pasar utama dari sebagaian besar pendapatan yang mereka terima (Todaro dan Smith, $2006:$ 393)

Pekerja sektor informal sangat dengan mudah di temui baik di kota besar maupun Kabupaten seperti halnya di Kabupaten PALI (Penukal Abab Lematang Ilir) khususnya di Pasar Bhayangkara Kecamatan Talang Ubi. Pasar bhayangkara merupakan pasar tradisional terbesar dan satusatunya di Kecamatan Talang Ubi bahkan seKabupaten PALI (Penukal Abab Lematang Ilir). Pasar bhayangkara sama seperti pasar tradisional lainnya menjual berbagai macam kebutuhan sehari-hari seperti lauk pauk, sayur mayur, buahbuahan, pakaian jadi, sandal, sepatu dan juga kue khas pasar tradisional. Para pekerja sektor informal di pasar Pendopo merupakan masyarakat yang bertempat tinggal di sekitar pasar dan pekerja sektor informal datangan selain itu ada juga terdapat pekerja sektor informal yang bersifat musiman, contohnya disaat musim buah tiba banyak pedangan membuka lapak di sepanjang jalan pasar pendopo, selain itu pada saat menjelang hari raya para pedagang kue akan terlihat memenuhi sepanjang jalan pasar pendopo.

Masyarakat yang bekerja pada sektor informal ini terdapat laki-laki maupun perempuan, namun kebanyakan perempuan dari pada laki-laki yang bekerja pada sektor informal ini, mereka yang bekerja di sektor informal ini rata-rata memiliki pendidikan rendah dan juga dengan modal kecil mereka bisa membuka usaha. Dari latar belakang ini peneliti tertarik untuk meneliti mengenai kondisi sosial ekonomi masyarakat yang bekerja di sektor informal, apakah penghasilannya dapat memenuhi kebutuhan sandang, pangan, papan pendidikan dan kesehatan mereka atau tidak, maka dari itu peneliti melakukan penelitian dengan judul; "Kondisi Sosial Ekonomi Masyarakat Yang Bekerja Pada Sektor Informal di Kelurahan Pasar Bhayangkara Kecamatan Talang Ubi Kabupaten Pali".

\section{METODOLOGI PENELITIAN}

Dalam hal ini fenomena yang akan Menurut Sugiyono (2012:2), metode penelitian adalah cara ilmiah untuk mendapatkan data dengan tujuan dan kegunaan tertentu. Metode yang digunakan dalam penelitian ini adalah metode deskriptif kualitatif, merupakan penelitian yang benarbenar hanya memaparkan apa yang terdapat atau terjadi di wilayah tertentu. Data yang terkumpul diklasifikasikan atau di kelompok-kelompokkan menurut jenis, sifat atau kondisinya. 
Penelitian kualitatif tidak bermaksud untuk menggambarkan karakteristik populasi atau menarik generalisasi kesimpulan yang berlaku bagi suatu populasi, melainkan lebih terfokus kepada representasi terhadap fenomena sosial . (Burhan Bungi, 2003 : 52). Teknik dan prosedur pengumpulan data. Teknik pengumpulan data adalah langkah yang paling utama dalam penelitian, karena tujuan utama dalam penelitian ini adalah mendapatkan data (Sugiyono, 2012:203). Pada peneitian ini teknik yang digunakan dalam pengumpulan data adalah teknik wawancara, dokumentasi dan observasi langsung.

Teknik dan prosedur analisis data dalam penelitian kualitatif, dilakukan pada saat pengumpulan data berlangsung, dan setelah selesai pengumpulan data dalam periode tertentu. Pada saat wawancara, peneliti sudah melakukan analisis terhadap jawaban yang diwawancarai. Bila jawaban yang diwawancarai setelah dianalisis terasa belum memuaskan, maka peneliti akan melanjutkan pertanyaan lagi, sampai tahap tertentu, diperoleh data yang dianggap kredibel. Miles dan Huberman (dalam Sugiyono, 2012:246), mengemukakan dalam analisis data kualitatif dilakukan secara interaktif dan berlangsung secara terus menerus sampai tuntas, sehingga datanya sudah jenuh. Analisis dilakukan melalui prosedur dan tahapan- tahapan berikut; 1) Data Reduction (Reduksi Data); 2) Data Display (Penyajian Data); 3) Conclusion Drawing/Veriffication (Sugiyono, 2012:252).

\section{HASIL DAN PEMBAHASAN}

Penelitian ini dilakukan di Pasar Pendopo Kelurahan Pasar Bhayangkara Kecamatan Talang Ubi Kabupaten Penukal Abab Lematang Ilir Sematera Selatan. Pada penelitian ini peneliti menggunakan 3 teknik pengumpulan data yaitu wawancara dokumentasi dan observasi. Penelitian ini dilakukan pada masyarakat yang bekerja pada sektor informal tujuannya untuk mengetahui apa saja faktor yang membuat masyarakat kelurahan pasar Bhayangkara bekerja di sektor informal dan bagaimana kondisi sosial ekonomi masyarakat yang bekerja pada sektor informal. Peneliti melakukan wawancara dengan beberapa pedagang di pasar pendopo tersebut, dalam penelitian ini peneliti menetapkan 5 jenis pedagang yang menjadi informannya yaitu pedagang ikan/ayam, pedagang sayur, pedagang kelontongan, pedagang pakaian jadi, dan pedagang buah, masing-masing dari 5 jenis pedagang tersebut di ambil 2 orang reponden untuk mewakili setiap jenis pedagang. Total responden yang di wawancara oleh peneliti yaitu 10 responden dan 1 informan kuncinya yaitu kepala pasar atau orang yang bertanggung jawab atas pasar tersebut.

Faktor penyebab masyarakat bekerja di sektor informal yaitu mengenai lapangan pekerjaan yang tersedia dan juga tingkat pendidikan, lapangan pekerjaan yang ada di kabupaten pendopo tidak banyak untuk mereka masyarakat yang hanya memiliki ijazah SD, SMP juga SMA, dapat diketahui bahwasanya masyarakat yang bekerja di bidang sektor informal ini memiliki tingkat pendidikan yang rendah,hal ini dikarenak kurangna pemahaman responden mengenai pentingnya pendidikan dimana jika kita memiliki tingkat pendidikan yang tinggi maka peluang untuk pekerjaaan yang leih baik akan semakin besar. Rendahnya tingkat pendidikan masyarakat kelurahan pasar Bhayangkara menyebabkan mereka haarus memasuki pekerjaan di sektor informal yang merupakan lapangan pekerjaan yang tidak memerluka pendidikan yan tinggi dan tidak memerlukan keahlian khusus, di sektor informal mereka bisa bekerja meskipun mereka tidak tamat sekolah sekalipun namun ada yang harus di kuasai dalam bekerja sebagai pedagang mereka harus bisa menghitung juga membaca.

Lingkungan sosial juga termasuk faktor mempengaruhi mesyarakat tersebut bekerja di bidang sektor informal, karena banyaknya masyarakat di sekitarnya yang bekerja di sektor informal maka itu menjadi salah satu pendukung untuk mempengaruhi responden untuk bekerja di sektor informal, memang perkembangan seseorang dapat di pegaruhi oleh lingkungan sosisl temapt ia berada seperti hanyalnya dengan responden yang berada di lingkungan teman bergaul yang bekerja di sektor informal. Berdasarkan wawancara yang sudah dilakukan masyarakat yang bekerja di sektor informal ini saat meraka pulang dari 
berdagang mereka tidak memiliki pekerjaan lain ada juga setelah berdagang di pasar mereka lanjut bekerja di kebun sebagai penyadap karet, karena karet merupakan sumber pendapatan masyarakat kelurahan pasar Bhayangkara selain mereka berdagang, namun untuk pedagang wanita setelang pulang berdagang mereka tidak memiliki pekerjaan lain kebanyakn mereka hanya menjadi ibu rumah tangga. Jadi tingkat pendidikan itu memeng sangat penting untuk kita karena jika semakin tinggi tingkat pendidikan yang kita miliki maka posisi dan juga pekerjaan yang akan kita terima itu akan semakin baik.

Keadaan pasar pendopo saat terjadi musim hujan, pasar menjadi becek dan terdapat banyak genangan air, itulah saat musim hujan terjadi akan memberi dampak bagi pendapatan para pedagang karena pasar akan lebih sepi saat musim hujan, orang-orang jadi lebih malas untuk pergi kepasar, namun ada juga bagi sebagian pedagang musim hujan tidak memberi dampak bagi pendapatan mereka. Tingkat keamanan yang ada di pasar pendopo ini terbilang bagus, karena menurut para responden yang di wawancarai bahwa pasar pendopo ini aman. Para responden yang di wawancarai kebanyakan mereka sudah berdagang lebih dari 5 tahun bahkan ada yang hampir lebih dari 10 tahun, untuk pendapatan yang mereka peroleh perharinya dari berdagang itu berfariasi, ada yang mengatakan bahwa yang mereka peroleh perhari itu hanya 200-400 ribuan, ada juga yang dapat sampai 700 ribuan perharinya dan jika saat sedagang ramai seperti bulan ramadan mendekati hari raya pendapatan yang mereka peroleh lebih bersar lagi karena saat-saat seperti itu pasar akan menjadi sangat ramai dan para responden yang berdagang di pasar pendopo itu bahkan pernah mendapatkan 1,5 juta perharinya. Jadi pendapatan para pedagang di pasar itu tidak menentu, pendapatan perharinya tergantung dari ramai atau tidaknya pasar saat itu. Para responden yang di wawancarai ini mereka tidak ada yang pernah menerima bantuan dari pemerintah.

Hasil dari wawancara dengan para pedagang ternyata kebanyakan dari mereka lebih memilih untuk bekerja dibandingkan hanya diam dirumah, alasannya karena jika mereka hanya diam saja dirumah maka mereka akan merasa bosan dan tidak ada pemasukan yang mereka terima, sedangkan mereka harus mencukupi kebutuhan mereka. Diketahui dari hasil wawancara bahwa pendidikan terakhir dari para pekerja sektor informal paling tinggi yaitu SMA dan kebanyakan dari mereka itu lulusan SD, itulah dapat di simpulkan bahwasanya jika kita memiliki tingkat pendidikan rendah maka kesempatan untuk kita bekerja di tempat yang lebih besar atau bekerja di perusahaa itu sangat sedikit kesempatannya, bahkan hampir tidak ada kesempatan, tingkat pendidikan memang mempengaruhi juga di mana dan akan kerja apa kita kelak, intinya pendidikan itu sangat penting. Dari wawancara yang dilakukan beberapa responden mengatakan bahwa tidak ada hambatan dalam mereka melakukan pekerjaan mereka dan ada yang mengatakan bahwa modal adalah hambatan atau penghambat dalam mereka bekerja, selebihnya tidak ada hambatan bagi mereka dalam bekerja di bidang sektor informal ini.

\section{SIMPULAN}

Berdasarkan dari penelitian bahwasanya masyarakat yang bekerja di sektor informal ini kebanyakan memiliki tingkat pendidikan yang rendah, umur mereka yang bekerja di sektor informal ini juga sudah 30 tahun keatas semua dan sudah bekerja di sektor informal ini semuanya hampir 10 tahun. Pendapatan yang mereka hasilkan perharinya dari berdagang bisa dikatakan itu mencukupi untuk kebutuhan mereka karena sekecil-kecilnya yang mereka terima perharinya yaitu 200 ribu rupiah dan hambatan yang mereka hadapi saat bekerja yaitu hanya masalah pada modal. Jadi kesimpulannya yang membuat mereka bekerja jadi pekerja sektor informal itu karena tingkat pendidikan atau ijazah yang mereke miliki yang tidak memungkinkan atau kecil kesempatannya untuk bekerja di tempat yang lebih besar lagi.

\section{DAFTAR PUSTAKA}

Hidayat, Komaruddin. and Widjanarko, Putut. (2008). Reinventing Indonesia : menemukan kembali masa depan bangsa. Jakarta : Mizan 
Masruroh, Nikmatul. (2018). Menggali Potensi Desa Berbasis Ekonomi Kerakyatan, Surabaya : CV. Jakad Publishing

Radhi, Fahmy. (2008). Kebijakan Ekonomi Pro Rakyat. Jakarta selatan : Republika

Todaro, Michael. P dan Smith. (1997). Pembangunan Ekonomi di Dunia Ketiga. Jilid $1 \&$ 2. Jakarta : Erlangga
Wibowo, Setyo A. (2004). Gaya filsafat Nietzsche. Yogyakarta : Galang Press

Sugiyono. (2012). Metode Penelitian Kuantitatif Kualitatif dan $R \& D$. Bandung: Alfabeta

Suharyono, Amien. (2013). Pengantar Filsafat Geografi. Yogyakarta: Penerbit Ombak. 